\title{
Al-okizan
}

ISSN 1907-0985, E ISSN 2442-8256

Vol. 16, No. 2, 2020, h. 375-400

DOI: https://doi.org/10.30603/am.v16i2.1901

\section{Kontekstualitas Fikih Perempuan di Indonesia}

\author{
Rizal Darwis
}

IAIN Sultan Amai Gorontalo

Email: rizaldarwis@iaingorontalo.ac.id

\begin{abstract}
In reality, women are still considered to be second to men, both from the private and social aspects. This article discusses the contextuality of women in the private and social spheres in Indonesia. This research was studied with a juridical, normative and sociological approach. The results show that the understanding of some people in understanding religion still places religious arguments related to misogynism in positioning men and women in the private and social spheres. Even though in some religious arguments it does not differentiate it. Likewise, in the state guarantee through statutory regulations in Indonesia, the position of citizens is equal before the state, both men and women in the private and public or social spheres.
\end{abstract}

Keywords: Islamic Jurisprudence, Women, Private, Social, Indonesia

\section{The Contextuality of Women's Islamic Jurisprudence in Indonesia}

\begin{abstract}
Abstrak: Perempuan dalam realitas masih dianggap menduduki posisi kedua dari laki-laki, baik dari aspek privat maupun aspek sosial. Artikel ini membahas kontektualitas perempuan dalam wilayah privat dan wilayah sosial di Indonesia. Penelitian ini dikaji dengan pendekatan fikih, yuridis normatif dan sosiologis. Hasil penelitian menunjukkan bahwa pemahaman sebagian orang dalam memahami agama masih menempatkan dalil-dalil agama terkait misoginis dalam memposisikan laki-laki dan perempuan pada wailayah privat dan wilayah sosial. Padahal dalam beberapa dalil-dalil agama tidak membedakannya. Begitu pula dalam penjaminan negara melalui aturan perundang-undangan di Indonesia menempatkan kedudukan warganegaranya sama di hadapan negara, baik laki-laki dan perempuan dalam wilayah privat maupun wilayah publik atau sosial.
\end{abstract}

Kata Kunci: Fikih, Perempuan, Privat, Sosial, Indonesia 


\section{A. Pendahuluan}

Allah swt. telah menciptakan segala sesuatu di dunia ini secara berpasangan (QS Yāsin/36 ayat 36, QS al-Zukhruf/43 ayat12, QS al-Zariyat/51 ayat 49); misalanya ada yang baik, ada yang buruk; ada yang gagah, ada yang cantik; ada yang jauh, ada yang dekat; ada yang laki-laki, ada yang perempuan; dan lain sebagainya. Penciptaan itu menandakan adanya keseimbangan yang hendak dicapai dalam menjalani kehidupan di dunia ini.

Selama berabad-abad silam, perempuan telah menjadi sorotan dari berbagai sisi, mulai dari sisi biologis, sisi sosiologis, sisi politik dan kekuasaan, hingga sisi agama. Bahkan pada sisi agama seringkali dijadikan sebagai sudut pandang yang paling konservatif dalam menyoroti perempuan. Persoalan perempuan menjadi sebuah diskusi yang hangat dalam tatanan perjalanan kehidupan manusia dengan mencermati akar sejarah yang cukup panjang. Hal ini tergambar dari adanya dominasi dari kaum laki-laki atas kaum perempuan. Juga diperparah lagi dengan adanya pemahaman keagamaan yang mendeskreditkan peran dan posisi perempuan.

Hidayanti dan Wulandari mengemukakan umat Yahudi dalam menyakini kitab sucinya yang tertuang dalam Kitab Perjanjian Lama memposisikan kaum perempuan sebagai sumber awal terjadinya kesalahan. Dikisahkan dalam Kitab Perjanjian Lama bahwa Hawa membujuk Adam untuk memakan buah Khuldi,sehingga inilah penyebab dikeluarkannya Adam dari surga. ${ }^{1}$ Selain itu, sejarah bangsa Arab pra-Islam menorehkan sejarah kelam status perempuan. Kala itu kaum perempuan tereksploitasi dikarenakan hak-haknya sebagian besar dihapuskan. Contohnya jika seorang isteri melahirkan seorang bayi perempuan, maka menjadi aib dan bencana bagi ayah dan pihak keluarganya, dan akhirnya bayi perempuan dibunuh. Selain itu, perempuan dapat diwariskan seperti harta warisan. ${ }^{2}$ Mencermati akar sejarah tersebut tampak bahwa perempuan kala itu

\footnotetext{
${ }^{1}$ Nor Hidayati dan Yanti Wulandari, "Peran Perempuan dan Tantangannya," dalam https://www.researchgate.net/publication/334063909_PERAN_PEREMPUAN_DAN_TANTAN GANNYA, diakses tanggal 8 Mei 2020.

${ }^{2}$ Zaituna Subhan, Al-Qur'an dan Perempuan Menuju Kesetaraan Gender dalam Penafsiran (Jakarta: Prenada Media Group, 2015), 4-7.
} 
posisinya menjadi manusia kelas dua (the second human being), dalam artian berada pada superioritas kaum laki-laki.

Menilik sejarah masa lampau sebelum kedatangan Islam, posisi perempuan ketika itu tidak mempunyai derajat kemanusiaan yang sempurna dan utuh, sehingga perempuan kala itu tidak dapat menyuarakan dan mengekspresikan dirinya dalam karya, serta memiliki harta. Kemudian setelah kedatangan Islam, melalui ajarannya mengangkat derajat kaum perempuan secara bertahap, sehingga memperolah kembali hak-haknya, seperti menyuarakan keyakinan dan kepercayaannya, mengaktualisasikan segala cipta dan karyanya, dan berhak mempunyai harta benda. Dengan cara ini perempuan mendapat pengakuan sebagai bagian dari masyarakat tersebut. Di sinilah misi Islam sejak kedatangannya tidak membedakan posisi perempuan berdasarkan jenis kelamin atau memberikan keutamaan pada jenis kelamin tertentu.

Islam sebagai agama wahyu yang bersifat universal menempatkan perempuan pada derajat terhormat. Ajaran Islam melalui firman Allah swt. menjelaskan penciptaan manusia itu terdiri dari laki-laki dan perempuan. ${ }^{3}$ Hal ini berarti bahwa kedudukan dan posisi perempuan sama dengan laki-laki tanpa membedakan antara satu dengan yang lainnya berdasarkan jenis kelaminnya. Namun walaupun demikian, masih ada saja dalam realita kehidupan masih menempatkan posisi perempuan dalam subordinasi dan termarginalkan, baik di ruang privat maupun ruang sosial, sehingga lahirnya gerakan emansipasi wanita, baik pada skala dunia internasional maupun skala nasional Indonesia.

Di Indonesia, perjuangan terhadap tuntutan adanya persamaan kedudukan laki-laki dan perempuan terus menerus disuarakan. Olehnya itu negara merumuskan kesetaraan jender sebagai salah satu kebijakannya. Namun persoalannya kemudian pada tataran implementasimya di lapangan masih terdapat diskriminasi jender dalam berbagai aspek kehidupan. Olehnya itu untuk membahas persoalan perempuan yang terpenting dimulai pada tataran pemahaman terhadap konsep perbedaan antara konsep seks atau jenis kelamin

${ }^{3}$ Lihat QS. al-Hujurat (49) ayat 13. 
dengan konsep jender. Hal ini perlu dilakukan dalam analisisnya karena ada keterkaitan yang erat antara konsep ketidakadilan jender dengan konsep seks atau jenis kelamin, sehingga jika tataran ini sudah selesai, maka untuk memahami dan menganalisis persoalan ketidakadilan yang terjadi pada kaum perempuan dapat terselesaikan. ${ }^{4}$

Untuk memajukan peran perempuan dalam ranah sosial dan pembangunan, maka kesetaraan jender tetaplah menjadi sorotan. Padahal lakilaki dan perempuan jika disorot berdasarkan kemampuannya secara intelektual maka kapasitas dan potensinya sama, namun jika dicermati dari kemampuan yang lebih spesifik yang disebabkan feminimnya, maka kesetaraan tersebut tentunya tidak tepat, yaitu dalam artian jika kesetaraan tersebut dilihat dari kacamata haruslah sama, yaitu perbandingan antara 50 dan 50, dan disinilah letak tidak akan terjadinya sebuah kesetaraan. Indikasi konsep kesetaraan itu antara laki-laki dan perempuan adalah keharusan memiliki kapasitas, kemampuan, kebutuhan dan kesukaan yang sama, sehingga antara keduanya yang ideal haruslah memperoleh tingkat pendidikan, pendapatan, kesehatan, dan partisipasi politik yang sama pula. ${ }^{5}$ Kesetaraan gender tersebut tetap menjadi agenda bagi negara-negara di dunia, tak terkecuali negara Indonesia.

Indonesia sebagai sebuah negara kepulauan (kepulauan nusantara) yang terdiri dari berbagai suku, ras, dan agama memberikan kontribusi terhadap pengarustamaan gender, misalnya dalam tataran agama dan ketatanegaraan. Khususnya ajaran Islam dengan sumber ajarannya dari Alquran, hadis Nabi saw. dan produk fikih memberikan pemahaman bahwa setiap individu, baik itu lakilaki maupun perempuan dalam menjalankan aktifitasnya tidak menunjukkan adanya pembedaan jenis kelamin. Begitupula dalam sistem ketatanegaraan Indonesia, khususnya dalam produk perundang-undangan di mana negara menjamin kesamaaan penduduk, baik dalam peran politik, pemenuhan pendidikan, pemenuhan ekonomi maupun di hadapan hukum.

\footnotetext{
${ }^{4}$ Rizal Darwis, "Hak Nafkah Batin Istri dalam Perkawinan: Telaah Fikih dan Hukum Nasional Perspektif Jender," Disertasi (Makassar: UIN Alauddin Makassar, 2016), 8.

${ }^{5}$ Dwi Edi Wibowo, "Peran Ganda Perempuan dan Kesetaraan Gender," Muwāzāh: Jurnal Kajian Gender, Vol. 3, No. 1, Juli 2011; 357-364.
} 
Produk perundang-undangan di Indonesia, misalnya Undang-Undang Nomor 39 Tahun 1999 tentang Hak Asasi Manusia (UU HAM) tampak sejalan dengan pemahaman fikih dalam konteks keindonesiaan. UU HAM menjelaskan aturan khusus hak-hak perempuan Indonesia. ${ }^{6}$ Dengan kata lain UU HAM memberikan cerminan atas fikih yang relevan dengan dalam konteks kekinian dan keindonesiaan. Misalnya pengakuan UU HAM akan fikih terkait perlunya ada perwalian bagi anak perempuan yang belum baliq (dewasa) dan belum menikah. Juga pada sisi yang lain, pemahaman fikih klasik masih menyatakan perempuan tidak berhak ikut andil dalam dunia politik, misalnya menjadi seorang pemimpin. Pemahaman fikih klasik inilah menjadi sangat kontradiktif dengan pemahaman fikih kekinian, khususnya di Indonesia. Padahal pada berbagai negara ternyata perempuan banyak yang tampil menjadi pemimpin negara, misalnya Gloria Arroyo Macapagal dan Cory Aquito di negara Filipina, Benazir Bhuto di negara Pakistan, Sirimanvo Bandaranaike di negara Sri Langka, Megawati Soekarno Putri di negara Indonesia dan lain sebagainya.

Ajaran Islam yang bersumber dari Alquran dan hadis Rasulullah saw. telah banyak memberikan pemahaman yang cukup jelas tentang kesetaraaan dan kesejajaran antara kaum laki-laki dan kaum perempuan. Islam sebagai agama ketuhanan sekaligus agama kemanusiaan dan kemasyarakatan (QS Āli 'Imrān/3 ayat112). Dalam pandangannya, manusia mempunyai dua kapasitas, yaitu sebagai hamba ('abijd) dan sebagai representatif Tuhan (khalifah) tanpa membedakan apa jenis kelamin, dari mana etnisnya dan warna apa kulitnya (QS al-Hujurāt/49 ayat 13). Kualitas kesalehan menurut pandangan Islam, tidak hanya didapatkan dengan cara penyucian diri (riyādhah al-nafsiyyah), akan tetapi juga perlu adanya kepedulian terhadap bagaimana penderitaan orang lain yang ada di sekitarnya (QS al-Mà'ūn/107 ayat 1-7). Sejak awal, ajaran Islam telah menekankan bahwa salah satu bentuk dari pelanggaran hak-hak asasi manusia adalah adanya diskriminasi terhadap peran dan relasi jender, dan hal

${ }^{6}$ Republik Indonesia, Undang-Undang No. 39 Tahun 1999 tentang Hak Asasi Manusia, pasal 45 sampai dengan pasal 51. 
demikian itu harus dieliminisir (QS al-Nisā'/4 ayat 75). Ajaran Islam telah memperkenalkan bagaimana konsep relasi jender yang mengacu kepada ayatayat Alquran yang substantif dan sekaligus menjadi tujuan umum syariah (maqāshid al-syarì'ah). ${ }^{7}$

Ketimpangan peran dan hak sosial perempuan dengan dalih agama inilah dipandang sebagai sebuah kesimpulan yang bermasalah dan perlu ditanyakan secara ontologis. Oleh karena itu, pandangan yang memposisikan perempuan tidak sejajar dan setara dengan laki-laki, baik dalam peran maupun hak sosial dapat dikatakan sebagai bentuk manipulasi tafsir agama dan antropologis yang merugikan dan memarjinalkan posisi kaum perempuan.

\section{B. Fikih Perempuan: Pemahaman terhadap Sebuah Defenisi}

Perempuan dalam sosoknya selalu menjadi sebuah daya tarik bagi para pemikir dalam kajian keilmuan dengan berbagai perspektif. Hal ini dikarenakan mempersoalkan perempuan laksana membahas lautan yang sangat luas dan tak bertepi. ${ }^{8}$ Peran perempuan memiliki dinamika sejarah yang panjang, mulai dari masa pra Islam, kenabian sampai pada masa modern ini. Di dunia Islam secara historis diperoleh informasi telah banyak fukaha yang membahas persoalan wanita atau perempuan dalam kajian khususnya, misalanya dalam kajian fiqh alnisā' atau fiqh al-mar'ah. Walaupun menurut Muhammad bahwa istilah fiqh almar'ah adalah sebuah istilah yang belum dikenal dalam khazanah keilmuan klasik, namun dalam perkembangannya ternyata banyak fukaha telah menulis

${ }^{7}$ Maqāshid al-syarī'ah secara terminologi berarti makna dan tujuan yang dikehendaki oleh syara' dalam menetapkan atau mensyariatkan semua atau sebagian besar hukumhukumnya, atau tujuan-tujuan dan rahasia-rahasia yang ditetapkan Allah swt. pada setiap hukum-Nya. Syariah pada intinya bertujuan untuk memelihara kemaslahatan umat manusia dan menghindarkannya dari mafsadah, baik di dunia maupun di akhirat. Bentuk kemaslahatan itu dikenal dengan isitlah lima unsur pokok (al-kulliyat al-khamsah), yaitu memelihara agama, memelihara jiwa, memelihara akal, memelihara keturunan dan memelihara harta. Kelima unsur pokok ini perlu diwujudkan dan direalisasikan dalam kehidupan. Lihat Ab- Ishaq Ibrāhim bin Mūsa al-Syatibi, Al-Muwāfaqat fỉ Ushūl al-Aḥkām, juz 2 (Kairo: Muhammad 'Ali Sabih, t.th.), 3 .

${ }^{8}$ Abū MuḥammadAșraf, Fatāwā al-Mar'ah al-Muslimah, Vol. 1 (Riyad: Aḍ̂ā' al-Salaf, 1996), 270. 
dalam karya terkait wanita atau perempuan. ${ }^{9}$ Sedangkan istilah fiqh al-nisa ${ }^{-}$ dikemukakan oleh Muhammad Shaḥrūr, seorang pemikir kontemporer asal Suriah dengan pandangan bahwa kata al-nis $\bar{a}^{-}$merupakan jamak dari kata almar'ah yang berarti wanita dewasa. Hal ini berdasar pada penafsirannya pada QS al-Nisā'/4 ayat 11 dan QS Ali Imran/3 ayat $14 .^{10}$

Kata fikih atau figh menurut etimologi diambil dari huruf atau akar kata $f \bar{a}, q \bar{a} f$, dan $h \bar{a}$, sehingga terangkai kata fiqh (فقه) yang mengandung arti paham atau pengetahuan tentang sesuatu. ${ }^{11}$ Pengertian fiqh secara terminologi dikemukakan oleh beberapa ulama, misalnya: Ibn Manzur menjelaskan bahwa alfiqh berarti pemahaman terhadap sesuatu atau pengetahuan terhadap sesuatu, dan selanjutnya jadilah sebuah istilah khusus bagi ilmu-ilmu keagamaan, dan terlebih khusus lagi bagi kasus-kasus parsial pada ilmu-ilmu hukum. ${ }^{12}$ Abū Zahrah mengemukakan fikih adalah ilmu terkait hukum-hukum syariat yang bersifat amaliyah, dan diambil dari dalil-dalilnya yang terperinci. ${ }^{13}$ Pengertian ini secara umum menyangkut empat kata kunci yang menjadi dasar, yaitu ilmu, hukum syariat, perbuatan manusia dan hasil ijtihad dari dalil tafshili (kasuistik), ${ }^{14}$ sehingga dapat dikatakan bahwa obyek fiqh itu ada dua, yaitu hukum-hukum yang bersifat amaliyah atau perbuatan jasmaniah, dan terkait dalil-dalil tentang hukum dari perbuatan jasmaniah atau amaliyah tersebut.

Ketika membahas term fiqh, maka sebenarnya adalah hukum Islam itu sendiri. ${ }^{15}$ Hukum Islam merupakan kata majemuk yang terdiri dari kata hukum dan kata Islam. Kata hukum yang telah diindonesiakan berasal dari bahasa Arab xxxviii.

${ }^{9}$ Husein Muhammad, Islam Agama Ramah Perempuan (Cirebon:Fahmina, 2004),

${ }^{10}$ Muḥammad Shahrūr, Naḥwa Ușūl Jadídah li al-Fiqh al-Islämī: Fiqh al-Mar'ah (Damaskus: Al-Ahālī, 2000), 255. Lihat juga Muhammad Shaḥūur, Al-Kitāb wa al-Qur'ān (Damaskus: Al-Ahālī, 1992), 643.

${ }^{11}$ Abū Husain Ahmad bin Fāris bin Zakariyah, Maqāyis al-Lughah, Juz IV (Bairūt: Dār al-Jail, 1981), 44.

${ }^{12}$ Ibn Manzur, Lisān al-'Arabī, Juz 12 (Bairūt: Dār al-Fikr, 1994), 522.

${ }^{13} \mathrm{Abū}$ Zahrah, Ushūl al-Fiqh (Mesir: Dār al-Fikr al-'Arabì, t.th.), 7.

${ }^{14}$ Muhammad al-Dausuqī dan Aminah al-Jabir, Muqaddimah fī Dirāsat al-Fiqh alIslämī (Qatar: Dauhah, 1411 H/1990 M), 13-22.

${ }^{15}$ Sadari, "KDRT dalam Perspekt if Fiqh," dalam Alimah (ed.), Ragam Kajian Kekerasan dalam Rumah Tangga (Cet. I; Cirebon: Institut Studi Islam Fahmina (ISIF) Cirebon, 2012), 151 . 
ḥukm (حكم). Kata ḥukm dari sudut etimologi (bahasa) berarti mencegah, ${ }^{16}$ secara legal, sesuai dengan aturan, pasti. ${ }^{17}$ Istilah hukum Islam adalah peistilahan dari bahasa Indonesia sebagai sebuah terjemahan al-Fiqh al-Isläm $\bar{i}$ atau dalam konteks tertentu dari al-syari'ah al-Islämi.. ${ }^{18}$ Dari tinjauan leksikalogisnya, hukum berarti menyelesaikan, atau memutuskan suatu hal, memberi kekang dan menghalangi keinginan seseorang. ${ }^{19}$ Dengan kata lain, hukum Islam yang lahir merupakan produk dari fiqh itu sendiri.

Selanjutnya untuk memahami arti perempuan, maka tidak terlepas dari persoalan fisik dan psikis perempuan itu sendiri. Jika perempuan dipandang dari sudutt fisik, maka didasarkan pada bagaimana struktur biologis dan perkembangan unsur kimia tubuh perempuan. Sedangkan jika perempuan dipandang dari sudut psikis, maka didasarkan pada sifat, feminitas dan maskulinitasnya. Di sinilah akan tergambar arti perempuan dalam konteks gender.

Pengertian perempuan secara etimologi dapat dilihat dari beberapa pandangan, antara lain menurut Subhan, kata perempuan berasal dari kata "empu" yang berarti dihargai, dan kemudian kata perempuan mengalami pergeseran ke kata wanita, di mana kata wanita berasal dari bahasa Sansekerta dengan kata dasar "Wan” yang artinya nafsu, sehingga wanita berarti yang dinafsui atau obyek seks. Namun dalam bahasa Inggris “wan" ditulis dengan "want," dengan bentuk lampau "wanted" yang berarti dibutuhkan atau dicari; bahasa Belanda ditulis "men;" bahasa Jerman ditulis "wun" dan "schen." Berdasarkan dari beberapa arti bahasa tersebut kesemuanya mengandung arti like, wish, desire, aim. Olehnya itu pengertian wanita, yaitu "who is being wanted" yang berarti seseorang yang dibutuhkan atau seseorang yang diingini. ${ }^{20}$

\footnotetext{
${ }^{16}$ Ibn Zakariyah, Mu’jam Maqāyis al-Lugah, Juz 2, 91.

${ }^{17}$ At abiq Ali, et. al., Kamus Kontemporer Arab Indonesia (Cet. II; Yogyakarta: Yayasan Ali Maksum Pondok Pesantren Krapyak, 1997), h. 786.

${ }^{18}$ Ahmad Rofiq, Hukum Islam di Indonesia (Cet. III; Jakarta: PT. Raja Grafindo Persada, 1998), 3.

${ }^{19}$ Ibrāhim Mustafa, Mu'jam al-Wasiț, Juz 2 (Teheran: al-Maktabah al-Islāmiyah, t.th.), 189.

${ }^{20}$ Zaitunah Subhan, Kodrat Perempuan: Takdir atau Mitos (Cet. I; Yogyakarta: Pustaka Pesantren, 2004), 19.
} 
Perempuan dalam bahasa Arab memiliki beberapa sinonim, yaitu term إمرأة , النساء, الأنثي (imra'ah, al-nisāa, al-unśāa). ${ }^{21}$ Term al-unśā mengandung arti "lembek atau lunak," dan lawan dari term al-zakara yang berarti "kuat." Perempuan dikatakan unśa disebabkan pada umumnya kulit perempuan itu lunak atau lembek. Selain itu, term al-nisā dan term niswah berasal dari kata nasiya yang mengandung arti "lupa," dan "menghibur." Berdasarkan hal tersebut dapat dipahami bahwa perempuan disebut al-nisā dikarenakan perempuan itu sering pelupa, dan begitu pula disebut niswah dikarenakan perempuan itu pandai dalam menghibur dirinya, utamanya menghibur suaminya. Olehnya itu, penggunaan term al-nisā atau niswah pada umumnya hanya menunjuk kepada kaum perempuan saja, baik itu statusnya anak-anak, gadis, isteri, maupun janda. Sedangkan term imra'ah yang berasal dari kata mir'ah yang mengandung arti "cermin." Hal ini mengandung arti perempuan suka bercermin pada umumnya, atau suka berhias diri di depan cermin. Jika melihat kenyataan term imra'ah ternyata lebih tepat untuk menyebut status apakah perempuan gadis, atau perempuan muda yang bersuami, atau janda, hal ini dikarenakan merekalah yang lebih suka berhias diri.

Selain pengertian di atas perempuan juga disebut perempuan dewasa, ${ }^{22}$ yaitu seseorang yang mengalami menstruasi(haid), hamil, dan melahirkan anak. Jika mencermati arti tersebut, maka dapat dilihat pengertiannya hanya menampilkan aspek fisik perempuan. Sebagaimana diungkapkan Broverman yang dikutip Fakih bahwa pada prinsipnya secara kodratnya manusia diciptakan dengan memiliki ciri biologis tertentu, baik itu berjenis kelamin laki-laki maupun perempuan. Laki-laki memiliki ciri biologis berupa dada yang datar, memiliki janggut, memiliki kumis, memiliki penis dan memproduksi sperma. Begitu pula perempuan memiliki alat reproduksi yang memproduksi sel telur, memiliki rahim, melahirkan, memiliki vagina, mempunyai payudara untuk menyusui, mengalami haid dan menopause. Kesemua ciri biologis tersebut

\footnotetext{
${ }^{21}$ Ahmad Warson al-Munawwir, Kamus al-Munawwir Arab Indonesia, Edisi II (Cet XXV; Surabaya: Pustaka Progressif, 1997), 1417.

${ }^{22}$ Departemen Pendidikan dan Kebudayaan, Kamus Besar Bahasa Indonesia (Cet. III; Jakarta: Balai Pustaka, 1994), 1125.
} 
melekat selamanya pada jenis laki-laki dan perempuan yang tidak bisa saling bertukar. $^{23}$

Allah swt. telah menciptakan perempuan dengan kelebihan-kelebihan yang lebih dari laki-laki dalam kaitannya dengan statusnya sebagai perempuan. Ciri khas perempuan yang secara biologis, yaitu mengalami kehamilan, melahirkan, dan menyusui. Namun dalam konteks persamaan dan kesetaraan antara laki-laki dan perempuan dalam ranah privat dan publik (sosial), maka aspek biologis dikesampingkan, sehingga melahirkan kesetaraan gender.

Fikih perempuan sebagai wacana menempatkan peran dan posisi dalam kesetaraan gender memiliki konsep pemaknaan bahwa lahir sebagai bentuk hukum-hukum amaliyah dalam pelaksanaan syariat, dan menjadi dalil-dalil terhadap hukum-hukum amaliyah tersebut. Olehnya itu fikih perempuan secara esensi merupakan hasil ijtihad para fuhaka dalam menginterpretasikan hukum syara' dan dalil-dalil, baik dalil naqli maupun dalil aqli. Hasil ijtihad inilah disebut dengan fiqh ijtihädi.

Ketika berbicara fiqh ijtihādi maka bisa jadi terdapat perbedaan pemahaman antara para ulama dalam menginterpretasikan perempuan dalam konteks kekinian, khususnya dalam konteks keindonesiaan. Hal ini bisa terjadi bahwa apa yang telah dirumusakan dalam fiqh klasik terkait persoalan perempuan pada masa Rasulullah saw, khulafaurrasyidin, dan tabi' tabi'in di jazirah Arab akan berbeda dengan persoalan perempuan di zaman modern ini, khususnya di Indonesia.

Mencermati tuntutan perubahan sosial yang terjadi dewasa ini, maka hukum Islam dan fiqh sebagai produk ijtihad ulama harus mampu memberikan sebuah solusi dan jawaban yang memuaskan bagi kebutuhan manusia. Olehnya itu hukum Islam dan figh harus dapast terlibat secara langsung dalam pemecahan segala persoalan manusia dalam ranah modernisasi dan globalisasi. Dalam artian, konsepsi hukum Islam dan fiqh harus lebih dekat kepada diri manusia dan

\footnotetext{
${ }^{23}$ Mansour Fakih, Analisis Gender \& Transformasi Sosial (Cet. VI; Yogyakarta: Pustaka Pelajar, 2008), 8.
} 
menjadikan hukum Islam dan figh untuk membumi pada kehidupaan dan diri manusia. $^{24}$

Gambaran dari hukum Islam ini sejalan dengan pandangan Ibn Qayyim alJauziyah sebagai berikut:

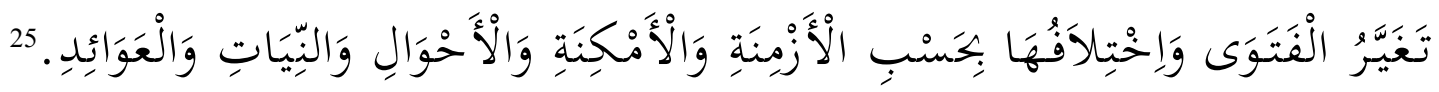
Artinya:

Adanya perubahan fatwa dan adanya perbedaan hukum yang terkait dengannya dikarenakan faktor zaman, faktor tempat, faktor situasi, faktor niat (motivasi) dan faktor kebiasaan (adat).

Pandangan al-Jauzi ini menunjukkan kehadiran syariat bertujuan mengantarkan kemaslahatan. Rasulullah saw, mengemban risalah kenabiaan di permukaan bumi melalui kehadiran syariat Islam dengan tujuan untuk mewujudkan sebuah keadilan hukum, kebajikan dan kemaslahatan, dan apabila tidak terpenuhi asas keadilan, kebajikan dan kemaslahatan pada setiap aturan atau hukum yang ditetapkan, maka dipandang bertentangan dengan syariat Islam itu sendiri.

Jika memahami pengertian figh dan syariat maka dalam pandangan Haq terdapat perbedaan pemaknaan, di mana syariat diambil dari nash-nash atau dalil-dalil bermuatan hukum yang berasal dari Allah swt. yang bersifat multak, universal, berlaku pada segala waktu dan tempat. Sedangkan fiqh merupakan produk mujtahid. Fiqh merupakan upaya dalam memahami hukum yang sifatnya relatif, hal ini dikarenakan ia lahir dari sebuah proses ijtihad dari ulama yang mengerahkan segenap potensinya, dan lahir pada konteks dan kondisi zaman dan lingkungannya. ${ }^{26}$

Harahap mengemukakan bahwa syariat adalah dasar dan ajaran Islam yang bersifat umum yang diwahyukan oleh Allah swt. dalam Alquran dan

\footnotetext{
${ }^{24}$ Rizal Darwis, "Pemikiran Ibnu Qayyim al-Jauziyah terhadap Paradigma Perubahan Hukum," Adzkiya: Jurnal Hukum dan Ekonomi Islam, Vol. 05, No. 1, Maret 2017; 68.

${ }^{25}$ Ibnu Qayyim al-Jauziyah, I'lam al-Muwaqqi'in 'an Rab al-'Alamin, Juz III (Bairut: Dar al-Fiqr, t.th.), 14.

${ }^{26}$ Hamka Haq, Syariat Islam; Wacana dan Penerapannnya (Cet. II; Makassar: Yayasan Ahkam, 2003), 27-28.
} 
dijelaskan oleh Rasulullah saw. melalui hadis. ${ }^{27}$ Alquran dan hadis berisikan hukum, kepercayaan (akidah dan nilai moral (akhlak). Kebenaran absolut Alquran hanya Allah-lah yang mengetahui dan Rasulullah saw. sebagai medium yang menghubungkan bahasa Allah dengan bahasa manusia. Kemudian karena syariat adalah seperangkat ajaran yang global, maka umat Islam perlu memahami dan menafsirkan ajaran-ajaran itu kedalam konteks partikular dengan melihat keadaan umat Islam yang beragama. ${ }^{28}$

Olehnya itu fiqh perempuan adalah sebuah konsep fikih yang dirumuskan oleh para fukaha melalui ijtihadnya sebagai bentuk dari penggunaan nalar dalam memahami nash-nash (dalil-dalil), baik nash (dalil) aqli dan nash (dalil) naqli, sehingga menetapkan sebuah hukum dengan mengkondisikan zaman dan tempat di hukum itu berlaku dalam rangka menghadirkan kemaslahatan.

\section{Fikih Perempuan dalam Konteks Keindonesiaan}

Islam sebagai agama paripurna mempunyai kepedulian yang sangat besar terhadap kaum perempuan. Keadilan sebagai salah satu dari misi pokok syariat Islam sangatlah menentang budaya misoginis masyarakat Arab. Hal ini tercatat dalam sejarah pra Islam seringkali membunuh bayi anak perempuan mereka. Oleh karena itu, Islam dengan seperangkat ajarannya menempatkan laki-laki dan perempuan setara dalam memperoleh hak-haknya, baik kaitannya dengan wilayah domestik maupun wilayah publik.

Konsep fikih perempuan yang dipahami sebagai bentuk hukum dari syariat Islam yang mengatur segala amal perbuatan manusia di dunia yang merupakan manifestasi dari ketundukannya kepada Allah swt. yang digali dari nash-nash (dalil-dalil) Alquran dan hadis Rasulullah saw. ${ }^{29}$ Terlebih khusus lagi

${ }^{27}$ Yahya Harahap, "Informasi Materi Hukum Islam: Mempositifkan Abstraksi Hukum Islam," dalam Cik Hasan Basri, ed., Kompilasi Hukum Islam dan Peradilan Agama (Jakarta: Logos Wacana Ilmu, 1999), 21-80.

${ }^{28}$ Atun Wardatun, Negosiasi Ruang antara RuangPublik dan Ruang Privat (Mataram: Pusat Studi Wanita IAIN Mataram, 2007), 63-64.

${ }^{29}$ Qathrun Nada, Sorotan terhadap Ide Rekonstruksi Fikih Perempuan: Sebuah Refleksi Semangat Pembaharuan, www.pesantrenonline.com, tanggal 2 Mei 2011. 
istilah fikih perempuan dimaknai sebagai pemikiran tentang hukum yang berkaitan atau mengatur tentang keperempuanan dalam berbagai aspeknya.

Olehnya itu, dalam konteks ini, fikih perempuan pada hakekatnya hasil pemahaman atau ijtihad ulama yang bersumber dari Alquran dan hadis yang mengatur keberadaan perempuan, baik pada wilayah domestik (privat) maupun di wilayah sosial (publik).

\section{Kontekstualitas Fiqh Perempuan dalam Kehidupan Rumah Tangga}

Perempuan dalam posisinya sebagai seorang isteri mempunyai kedudukan sangat penting dan menentukan dalam kehidupan rumah tangga. Hal ini dikarenakan kehidupan yang dijalani adalah sebuah hubungan kerjasama kedua belah pihak antara suami isteri untuk mewujudkan kehidupan yang sakinah, mawaddah wa rahmah, yaitu rumah tangga yang tenang, dipenuhi cinta dan kasing sayang. Untuk mewujudkan hal tersebut, Alquran memberikan petunjuk bagi pasangan suami isteri. Misalnya bagi suami ada petunjuk seperti yang dalam QS. al-Nisā (4) ayat 19, yakni, وَعَاثِدروهُنَّ بِالْكَعْرُوفِ (dan pergauliah mereka/isteri-isteri dengan cara yang ma'ruf). ${ }^{30}$ Sedangkan untuk isteri misalnya ada petunjuk untuk dipedomani sebagaimana terdapat dalam QS. al-Baqarah (2)

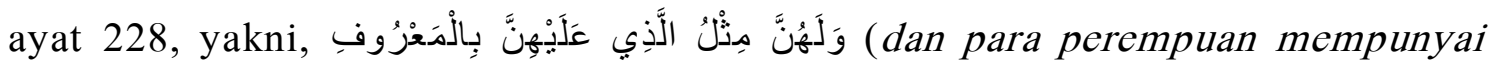
hak yang setimpal dengan kewajibannya dengan cara-cara yang ma'ruf). ${ }^{31}$ Berdasarkan informasi dari kedua ayat tersebut diketahui bahwa suami dan isteri dalam hubungannya haruslah berdasarkan pada prinsip mu'āsyarah bi al-ma'rūf.

Definisi mu'āsyarah bi al-ma'rūf merupakan bentuk pergaulan antara suami isteri, layaknya pertemanan dan persahabatan yang dibangun secara kekeluargaan dan kekerabatan dengan cara-cara yang baik. ${ }^{32}$ Dengan kata lain, adanya prinsip mu'asyarah bi al-ma'rū fyang menjadi landasan yang dipedomani pasangan suami isteri dalam membangun kehidupan rumah tangganya, sehingga

\footnotetext{
${ }^{30}$ Kementerian Agama RI, Ummul Mukminin: Al-Qur'an dan Terjemahan Bagi Wanita (Jakarta: Penerbit Wali, 2010), 119.

${ }^{31}$ Ibid., 55.

${ }^{32}$ K. H. Husein Muhammad, Fiqh Perempuan (Yogyakarta: LkiS, 2001), h. 10.
} 
jika terjadi persoalan-persoalan dalam urusan rumah tangga pasangan suami isteri tersebut, maka bisa diselesaikan dengan cara-cara yang baik.

Pada era kekinian di Indonesia, masih sering ditemukan terjadinya di dalam kehidupan rumah tangga kaum muslim Indonesia, suami masih dianggap sebagai orang yang memiliki kedudukan tertinggi dalam hal pengambilan keputusan. Hasil penelitian pada perempuan Karo di Desa Galang memperlihatkan pola relasi yang tidak seimbang (asimetris) dalam aktifitas keseharian yang dilakukan oleh laki-laki (suami) dengan perempuan (isteri) yang berpengaruh pada kehidupan rumah tangga mereka. Walaupun perempuan (isteri) bekerja dan memiliki penghasilan sendiri, namun dalam hal urusan rumah tangga seperti memasak, mencuci, membersihkan rumah, dan merawat anak masih tetap dilakukan perempuan Karo, sehingga nampak adanya beban kerja yang berlebihan yang dialami isteri. Juga dalam pengambilan keputusan keluarga, perempuan Karo (isteri) lebih mentaati perkataan suami. ${ }^{33}$ Hal ini berarti perempuan (isteri) harus taat kepada segala ketentuannya. Jika isteri berusaha untuk melanggarnya, maka akan dianggap telah melakukan nusyūz.

Kata nusyūz diambil dari kata nasyaza dalam bahasa Arab yang dalam bahasa Indonesianya berarti perempuan yang mendurhaki suaminya, ${ }^{34}$ sedangkan menurut terminologi dari Al-Zuhaily bahwa nusyūz adalah pengingkaran (maksit) isteri terhadap kewajibannya kepada suaminya, juga perkara yang menyebabkan salah satu dari pasangan suami isteri benci dan keluar pergi dari rumah tanpa izin suami dan keluarnya buka untuk mencari keadilan kepada hakim. ${ }^{35}$ Sabiq mengemukakan bahwa nusyūz adalah kedurhakaan isteri kepada suaminya, tidak taat atau menolak untuk diajak ke tempat tidurnya, atau keluar rumah tanpa izin dari suaminya. ${ }^{36}$ Juga dalam Kompilasi Hukum Islam dijelaskan "Isteri dapat dianggap nusyuz jika ia tidak mau melaksanakan

\footnotetext{
${ }^{33}$ Jesika Monalisa Perangin Angin, "Ketidakadilan Pola Relasi Gender Pada Masyarakat Karo di Desa Galang Kecamatan Galang Kabupaten Deli Serdang," Skripsi (Medan: Universitas Sumatera Utara, 2018)

${ }^{34}$ Indrus H. Al-Kaff, Kamus Praktik Al-Qur'an (Bandung: Fokus Media, 2007), 20.

${ }^{35}$ Wahbah al-Zuhaili, Al-Fiqh wa Adillatuh, Juz 7 (Beirut: Dār al-Fikr, t.th.), 338.

${ }^{36}$ Sayyid Sabiq, Fiqh Sunnah, Jil. 2 (Madinah: Al-Fatkh li I'lām al-Arabì, 1990), 314.
} 
kewajiban-kewajiban sebagaimana dimaksud dalam pasal 83 ayat (1) kecuali dengan alasan yang sah." 37 Kemudian dijelaskan kriteria nusyüz, yaitu "Kewajiban utama bagi seorang isteri ialah berbakti lahir dan batin kepada suami di dalam yang dibenarkan oleh hukum Islam." ${ }^{38}$

Oleh karena itu pada prinsipnya nusyūz meliputi segala hal yang tidak disenangi oleh suaminya, baik itu sifatnya lahir maupun batin. Namun hal ini menjadi sebuah permasalahan jika konteks nusyüz dijadikan sebagai pembenaran oleh suami dalam melakukan tindakan kesewenang-wenangan kepada isteri, maka perlu dipahami dalam konteks fikih kekinian dan keindonesiaan.

Pemahaman konsep nusyūz dalam konteks fikih kekinian dan keindonesiaan hendaknya diberikan ruang yang tepat dan proporsional untuk menghindari terjadinya bias jender. Hal ini rawan dilakukan oleh pihak suami jika merasa tindakan isteri yang tidak sesuai dengan keinginannya dianggap sebagai sebuah tindakan nusyūz. Olehnya itu Pemerintah Indonesia telah membuat aturan perundang-undangan, yaitu Undang-Undang Nomor 23 Tahun 2004 tentang Penghapusan Tindak Kekerasan Dalam Rumah Tangga (selanjutnya disebut UUPKDRT) yang memberikan jaminan terhadap suatu pelanggaran dan kesewenang-wenangan dari pihak suami maupun isteri.

Kekerasan terhadap sesama manusia tidak mengenal batas ruang dan waktu, bisa terjadi di ruang publik dan ruang domestik (rumah tangga). Pelaku kekerasan dalam rumah tangga didominasi oleh laki-laki, baik suami terhadap isterinya maupun ayah terhadap anak-anaknya. ${ }^{39}$ Menurut UUPKDRT menyebutkan beberapa bentuk kekerasan, yaitu kekerasan fisik, kekerasan psikis, kekerasan seksual dan penelantaran rumah tangga. ${ }^{40}$ Bentuk kekerasan psikis yang dilakukan seorang suami kepada isterinya berupa pengabaikan hak nafkah batinnya. Nafkah batiniyah ini adalah segala sesuatu kebutuhan batin

\footnotetext{
${ }^{37}$ Republik Indonesia, Instruksi Presiden Nomor 1 Tahun 1999 tentang Penyebarluasan Kompilasi Hukum Islam, Pasal 84 ayat (1).

${ }^{38}$ Ibid., Pasal 83 ayat (1).

${ }^{39}$ La Jamaa dan Hadidjah, Hukum Islam dan Undang-Undang Anti Kekerasan dalam Rumah Tangga (Cet. 1; Surabaya: Bina Ilmu, 2008), 1.

${ }^{40}$ Republik Indonesia, Undang-Undang Nomor 23 Tahun 2004 tentang Penghapusan Kekerasan dalam Rumah Tangga, Pasal 5.
} 
isteri setelah terjadi akad nikah yang sah, seperti memberikan kepuasan seksual, menjaga perasaan isteri, perlindungan dan perlakuan yang baik. ${ }^{41}$

Padahal perkawinan dengan akad nikah secara sah menyebabkan timbulnya hak dan kewajiban bagi pasangan suami isteri. Pasangan suami isteri dituntut untuk menunaikan kewajibannya masing-masing, sehingga tidak terjadi pengabaian dan kelalaian. Pemenuhan hak dan kewajiban haruslah berupaya melakukan pendekatan ke arah keserasian dan pemahaman antar masing-masing pasangannya. $^{42}$

Pendekatan fikih Indonesia kekinian memberikan peluang kepada perempuan dalam urusan rumah tangga hendaknya dibangun dalam konsep kesetaraan dan keadilan gender. Keseimbangan dan kesetaraan sesungguhnya pada masa pra-nikah sudah ada dalam konsep ajaran Islam, yaitu konsep sekufu. $^{43}$ Ini menjadi salah satu syarat dasar bahwa untuk melangsungkan perkawinan sesungguhnya modal utama adalah mewujudukan kesetaraan antara pihak laki-laki dan pihak perempuan.

Darwis mengemukakan konsep kesetaraan atau se-kufu dalam perkawinan Islam, antara lain:

a. Kesetaraan dalam penentuan pilihan pasangan

Persoalan ini menjadiperhatian dikarenakan adanya hak ijbār dan wali mujbir. Wali mujbir sebagaimana dijelaskan dalam kitab fikih klasik adalah ayah atau kakek dari seorang gadis. Hak ijbār adalah hak yang dimiliki untuk memaksakan sebuah perkawinan pada seorang gadis. Olehnya itu jika ada seorang anak gadis yang tidak mau mengikuti perkawinan yang ditentukan oleh wali mujbir-nya, maka akan dicap sebagai anak durhaka dan telah melakukan perbuatan dosa.

\footnotetext{
${ }^{41}$ Satria Effendi M. Zein, "Hak Nafkah Batin Isteri dan Ganti Rugi Berupa Materi," Mimbar Hukum dan Aktualisasi Hukum Islam, No. 3 Tahun II, 1991; 32.

${ }^{42}$ Rizal Darwis, "Hak Nafkah Batin Isteri dan Kesetaraan Jender dalam Perkawinan: Analisis terhadap Konsep Hukum Islam dan Hukum Nasional Indonesia," dalam Abdul Wahid, et.al., Islam Indonesia Pasca Reformasi: Dinamika Keagamaan Pada Ranah Sosial, Politik, Budaya, Hukum dan Pendidikan (Cet. 1; Surabaya: Imtiyaz, 2015), 131.

${ }^{43}$ Ibid., 135.
} 
Mencermati konsep ini sebenarnya ada kaitannya dengan kedudukan wali dalam sebuah perkawinan, apakah menjadi syarat sah atau tidaknya sebuah perkawinan? Ulama berbeda pendapat dalam hal ini; pendapat pertama yang didasarkan oleh riwayat Aisyah bahwa tiada perkawinan tanpa adanya wali, sehingga ini menjadi syarat sahnya perkawinan; dan pendapat ini didukung oleh Imam Syafi'i. ${ }^{44}$ Pendapat kedua, pernikahan dengan tidak adanya wali adalah sah jika calon suaminya se-kufu (sebanding). Pendapat ini didukung oleh Abu Hanifah, Zufar, al-Syaibi dan al-Zuhri. ${ }^{45}$

Persoalan wali nikah di Indonesia ditetapkan dalam Kompilasi Hukum Islam (KHI) bahwa "yang bertindak sebagai wali nikah ialah seorang laki-laki yang memenuhi syarat hukum Islam, yakni muslim, aqil dan balig". ${ }^{46}$ Kemudian dalam pelaksanaannya, akad nikah atau ijab dan qabul, penyerahannya (ijab) dilakukan oleh wali mempelai perempuan atau yang mewakilinya, dan penerimaannya (qabul) oleh mempelai laki-laki. Sedangkan Undang-Undang Nomor 1 Tahun 1974 tentang Perkawinan, persoalan wali nilak tidak diatur secara eksplisit, namun hanya dinyatakan dalam pasal 26 ayat (1) bahwa:

Perkawinan yang dilangsungkan di muka Pegawai Pencatat Nikah yang tidak berwenang, wali nikah yang tidak sah, atau yang dilangsungkan tanpa dihadiri oleh 2 (dua) orang saksi dapat dimintakan pembatalannya oleh para keluarga dalam garis keturunan lurus ke atas dari suami isteri, jaksa dan suami atau isteri.

Pasal 26 ayat (1) secara implisit mengisyaratkan bahwa perkawinan yang tidak diikuti wali, maka batal atau dapat dibatalkan. Namun ini berbeda jika pasangannya tersebut telah hidup bersama sebagai suami isteri dalam hubungan perkawinan, maka hak untuk membatalkannya menjadi gugur. Hal ini sejalan

${ }^{44}$ Ibn Rusyd, Bidayah al-Mujtahid, Jil. 2, terj. Imam Ghazali Said dan Ahmad Zaidun, Bidayatul Mujtahid (Jakarta: Pustaka Amani, 2007), 409.

${ }^{45}$ Ibid. 409.

${ }^{46}$ Departemen Agama RI., Kompilasi Hukum Islam (Jakarta: Direktorat Pembinaan Agama Islam, 1991), pasal 20 ayat (1).

${ }^{47}$ Republik Indonesia, Undang-Undang No. 1 Tahun 1974 tentang Perkawinan, pasal 26 ayat (1). 
dengan ketentuan fikih Islam yang dipahami selama ini, yakni fikih mazhab Syafi'i yang mayoritas dianut oleh masyarakat Indonesia. ${ }^{48}$

Jika dicermati dengan seksama hak ijbar yang dimiliki orangtua atau wali sesungguhnya tidaklah menjadi hak mutlak yang tidak boleh diganggu gugat sebagaimana hak veto. Adanya hak ijbar pada prinsipnya memberikan pemahaman adanya hak dan kewenangan seorang wali mujbir, adanya hak ijbar dimaksudkan untuk memberi kesempatan kepada orang tua atau wali untuk berbuat yang terbaik dan peduli terhadap masa depan anak perempuannya, termasuk dalam memilihkan jodoh. ${ }^{49}$ Namun terkadang dengan aturan hak ijbar ini, tidak mengherangkan masih banyak perempuan Indonesia, terutama di pedesaan menerima saja bentuk perkawinan tersebut, di mana dalam kenyataannya masih sering dijumpai perempuan tidak berdaya menghadapi pilihan orang tuanya, padahal mereka tidak menginginkannya.

b. Kesetaraan fungsi dan perannya dalam keluarga

Perempuan dalam statusnya sebagai isteri dan ibu dari anak-anaknya memiliki hak yang cukup penting dan mendasar dalam keluarga, yaitu hak untuk memperoleh jaminan kesejahteraan. Dalam istilah fikih dikenal dengan nama nafkah. Prinsip dasar dalam penetapan kewajiban suami memberi nafkah adalah dalam rangka menjaga anggota keluarga dari kesengsaraan. Hal ini berkaitan dengan fungsi dan peran isteri sebagai pelaku reproduksi (mengandung, melahirkan, menyusui dan merawat anak) yang tidak bisa dialihperankan kepada suami. Peran dan fungsi tersebut secara kodrati memang diperuntukkan bagi perempuan (isteri), namun pada waktu lain peran dan tugas kerumahtanggaan (mengelola rumah tangga, merawat dan menjaga anak, mendidik anak) dapat pula dikerjakan oleh laki-laki (suami).

c. Kesetaraan dalam menikmati hubungan seksual

Persoalan hubungan seksual suami istri akan dipengaruhi oleh konsep dasar perkawinan. Ada dua pandangan, yaitu: Pertama, jika perkawinan

\footnotetext{
${ }^{48}$ Siti Musda Mulia, Muslimah Reformis: Perempuan Pembaru Keagamaan (Cet. I; Bandung; Mizan, 1425 H./2005 M), 359.

${ }^{49}$ Rizal Darwis, "Hak Nafkah Batin Isteri," 136.
} 
diartikan sebagai akad tamlik (kontrak kepemilikan), maka pernikahan seorang suami telah melakukan kontrak pembelian perangkat seks (bud'u) sebagai alat melanjutkan keturunan dari pihak perempuan yang dinikahinya, sehingga dalam konsep ini suami adalah pemilik perangkat seks tersebut dan ini menyebabkan hubungan seks sepenuhnya tergantung kepada pihak suami, dan istri tidak memiliki pilihan kecuali melayaninya; Kedua, jika perkawinan diartikan akad ibahah, yaitu kontrak untuk membolehkan sesuatu, dalam hal ini alat seks yang semula dilarang menjadi halal. Artinya dengan perkawinan tersebut alat seks yang perempuan tetap merupakan milik perempuan yang dinikahi, hanya saja alat seks tersebut halal untuk dinikmati oleh suaminya akibat hubungan perkawinan. Di sini hubungan seks tidak semata-mata milik suami, akan tetapi tergantung atas kehendak bersama suami istri. ${ }^{50}$

Persoalannya kemudian terjadi kecenderungan masyarakat di Indonesia bahwa hubungan seksual suami istri lebih banyak dinikmati oleh suami, sementara istri hanya melayani. Hal ini dipengaruhi oleh pemahaman fikih bahwa hubungan seks bagi istri adalah semata-mata kewajiban kepada suami. Olehnya itu perlu adanya pemahaman fikih perempuan bahwa dalam konsep hubungan suami istri adalah konsep mu'asyarah bi al-ma'rūf. Konteks kekinian dan keindonesiaan diperlukan suatu paradigma fikih perempuan yang memberikan hak dan peluang sama antara laki-laki dan perempuan dalam kehidupan tangga. Hal ini penting sebagai respon terhadap paradigma fikih yang menempatkan perempuan secara tidak adil. Padahal hakikat atau substansi dari keseluruhan ajaran Islam adalah keadilan atau keseimbangan. Bahkan tidak berlebihan jika dikatakan bahwa semua tafsir atau fikih yang tidak berkeadilan atau seimbang harus ditolak atau direkonstruksi karena dipandang bertentangan dengan ajaran Islam.

Oleh sebab itu memberikan peluang kepada para perempuan dalam menentukan pasangannya merupakan salah satu bentuk fikih kekinian, di mana secara proporsional memperoleh hak-hak dan kewajiban yang adil dan seimbang

\footnotetext{
${ }^{50}$ Ibid., $141-142$.
} 
dalam kehidupan perempuan. Menciptakan kesetaraan derajat adalah ruh dari ajaran Islam.

Syariat Islam bersifat normatif dan fleksibel, sehingga di samping terdapat ajaran yang normatif, juga terdapat ajaran yang memiliki relevansi dengan perkembangan zaman. Oleh karena itu, fikih harus dilihat dan dikembangkan sesuai dengan konteksnya. Salah satu contoh dalam QS. al-Nisa (4) ayat 34, Allah swt. berfirman:

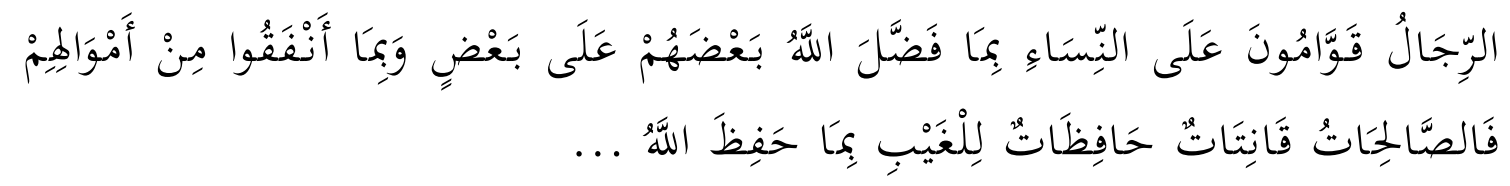

Terjemahnya:

Kaum laki-laki itu adalah pemimpin bagi kaum wanita, oleh karena Allah telah melebihkan sebagian mereka (laki-laki) atas sebagian yang lain (wanita) dan karena (laki-laki) telah menafkahkan sebagian dari harta mereka. Sebab itu, maka wanita yang saleh, ialah yang taat kepada Allah lagi memelihara diri ketika suaminya tidak ada, oleh karena Allah telah memelihara (mereka) ....

Jika memahami secara tektual ayat tersebut kelihatannya memperlakukan perempuan secara kasar, namun sebenarnya tidak demikian. Berdasarkan asbāb al-nuzūl ayat tersebut, keberadaan wanita kala itu dibatasi hanya boleh di dalam rumah dan yang keluar dari rumah hanyalah laki-laki untuk menghidupinya. Di sini nampak bahwa Alquran sangat memperhitungkan kondisi seperti ini dan menempatkan kedudukan laki-laki pada posisi yang lebih superior daripada perempuan. Perlu dicermati pula bahwa Alquran tidak menganggap atau menyatakan bahwa stuktur sosial bersifat normatif. Suatu struktur sosial pasti menentukan bahwa perempuanlah yang menghidupi keluarganya, atau menjadi teman kerja laki-laki, maka perempuan pasti sejajar, bahkan lebih superior daripada laki-laki. ${ }^{52}$

Dengan demikian, fikih perempuan kontemporer, kekinian dan keindonesiaan menghendaki suatu paradigma fikih yang memberikan

\footnotetext{
${ }^{51}$ Kementerian Agama RI., Ummul Mukminin: Al-Qur'an dan Terjemahan, 131.

${ }^{52}$ M. Quraish Shihab, Wawasan Alquran: Tafsir Maudhu'i atas Pelbagai Persoalan Umat (Cet. III; Bandung: Mizan, 2003), 302.
} 
perlindungan perempuan dalam memperoleh hak-haknya. Artinya bahwa paradigma fikih perempuan dalam konteks kekinian dan keindonesiaan yang ideal adalah fikih yang dirumuskan untuk menjamin hak-hak perempuan.

\section{Fiqh Perempuan dalam Kehidupan Masyarakat}

Beberapa waktu silam marak diperbincangkan dan diperdebatkan oleh kalangan birokrat, akademisi dan agamawan tentang peran perempuan dalam kehidupan sosial masyarakat, utamanya dalam hal kepemimpinan pada wilayah publik. Hal ini seringkali menjadi sorotan terhadap kaum perempuan di era kekinian terkait persoalan kepemimpinan perempuan di tengah-tengah masyarakat.

Perspektif yang digunakan sebagian pihak dalam mempersoalkan peran perempuan di ruang publik adalah perspektif agama dengan mengambil rujukan di dalam Alquran dan hadis. Misalnya QS al-Nisa (4) ayat 34 yang menyebutkan kaum laki-laki itu pemimpin kaum perempuan. Namun ayat ini menjadi kontroversial, sehingga diperlukan sebuah konsep fikih yang lebih sesuai dengan kondisi berkembang di era kekinian.

Selain QS al-Nisa (4) ayat 34, juga dalam hadis dinyatakan:

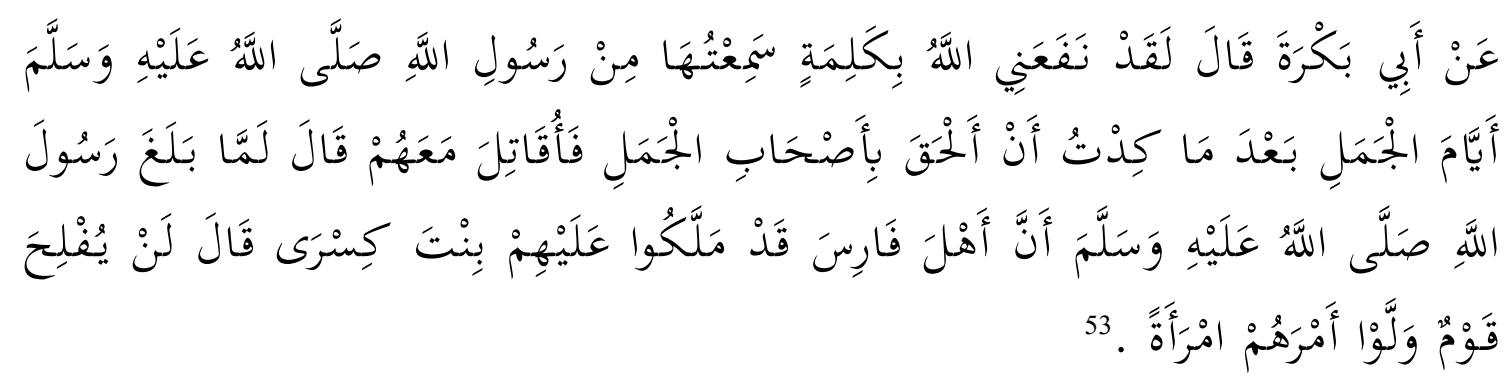

Artinya :

Dari Abi Bakrah berkata bahwa sesungguhnya Allah telah memberikan manfaat kepada saya dengan cerita yang saya telah dengar dari Rasulullah saw. berkaitan dengan Perang Jamal yang saya terlibat dalam peperangan tersebut. Lalu Abi Bakrah berkata: sebagaimana Rasulullah bersabda bahwa sesungguhnya penduduk Persia dibawah kekuasaan Binti Kisra, setelah Rasulullah mengetahui hal itu, beliau bersabda: Tidak akan berunt ung suatu kaum ketika kepemimpinan diberikan kepada wanita (HR. Bukhari)

\footnotetext{
${ }^{53} \mathrm{Abū}$ 'Abd. Allāh Muhammad ibn Ismā'̄il ibn Ibrāhim ibn al-Mugīrah ibn al-Bardizbāt al-Bukhāri, Sah̄h al-Bukhāriy, Juz V (Bairut: Dar al-Kutb al-Ilmiyah, 1412 H/1992 M), 160 .
} 
Jika mencermati secara tekstual QS al-Nisa (4) ayat 34 dan riwayat Abi Bakrah tidak membenarkan kaum perempuan menjadi pemimpin dalam berbagai medan dan wilayah. Namun jika merujuk pada pemaparan Shihab dalam memahami arti qawāmah adalah pemenuhan kebutuhan, perhatian, pemeliharaan, pembinaan dan pembelaan. ${ }^{54}$ Jika di bawah kepada ranah politik, ciri kekuasaan tidak harus bertolak belakang dengan sifat-sifat feminim, seperti lemah lembut, tampil cantik dan menarik, mau mengalah dengan sukarela dan tulus memberikan pujian, namun dengan kekuatan feminisme perempuan dapat memperkaya bidang politik dan pada akhirnya laki-laki dapat menghargai perempuan sebagai mitra dan bukan saingan laki-laki. ${ }^{55}$

Alquran menggambarkan figur seorang muslimah adalah memiliki kemandirian politik (al-istiqlāl al-siyāsah), ${ }^{56}$ seperti figur Ratu Balqis yang memimpin kerajaan superpower ('arsyun 'azhīm), ${ }^{57}$ memiliki kemandirian ekonomi (al-istiqlāl al-iqtisādiy), ${ }^{58}$ figur pengolah peternakan sebagaimana dalam kisah Nabi Mūsa as. di Madyan. ${ }^{59}$ Perempuan yang telah menikah memiliki figur kemandirian dalam menentukan pilihan pribadi (al-istiqlāl alsyakhsi) yang diyakini kebenarannya, sekalipun berhadapan dengan suami, ${ }^{60}$ atau menentang pendapat orang banyak (publik opinion) bagi perempuan yang belum menikah. ${ }^{61}$ Juga kaum perempuan bisa melakukan gerakan opisisi terhadap segala bentuk sistem yang bersifat tirani demi tegaknya kebenaran. ${ }^{62}$

Melalui ajaran Islam dapat diketahui kedatangannya hadir sebagai bentuk persaudaraan universal, kesetaraan dan keadilan sosial. Hal ini terkandung dalam firman Allah swt. pada QS. al-Hujurat (49) ayat 13.

\footnotetext{
${ }^{54}$ M. Quraish Shihab, Membumikan Al-Qur'an: Fungsi dan Peran Wahyu dalam Kehidupan Masyarakat (Cet. 1; Bandung: PT Mizan Pustaka, 2013)

${ }^{55}$ Musdah Mulia, Ensiklopedia Muslimah Reformis: Pokok-Pokok Pemikiran untuk Reinterpretasi dan Aksi (Cet. 1; Tangerang Selatan: Baca, 2020), 402.

${ }^{56}$ Lihat QS. al-Mumtahanah (60) ayat 12.

${ }^{57}$ Lihat QS. al-Naml (27) ayat 23.

${ }^{58}$ Lihat QS. al-Nahl (16) ayat 97.

${ }^{59}$ Lihat QS. al-Qashash (28) ayat 23.

${ }^{60}$ Lihat QS. al-Tahrīm (66) ayat 11.

${ }^{61}$ Lihat QS. al-Tahrīm (66) ayat 12.

${ }^{62}$ Lihat QS. al-Taubah (9)ayat 71.
} 


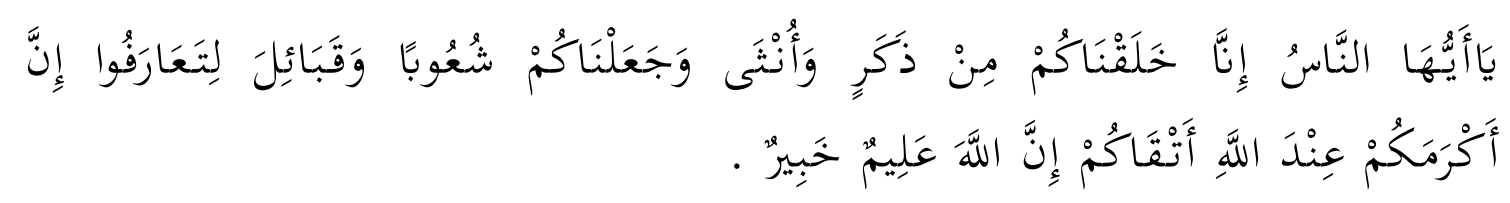

Terjemahnya:

Hai manusia, sesungguhnya Kami menciptakan kamu dari seorang laki-laki dan seorang perempuan dan menjadikan kamu berbangsa-bangsa dan bersuku-suku, supaya kamu saling mengenal. Sesungguhnya orang yang paling mulia di antara kamu di sisi Allah ialah orang yang paling takwa di antara kamu. Sesungguhnya Allah Maha Mengetahui lagi Maha Mengenal. ${ }^{63}$

Berdasarnya pernyataan QS. al-Hujurat (49) ayat 13 tersebut secara tegas membantah adanya konsep superioritas ras, kesukuan, kebangsaan dan kekeluargaan, akan tetapi memberikan seruan akan pentingnya kesalehan sosial. Bentuk keadilan sangat ditekankan oleh Islam pada semua aspek kehidupan, tanpa membedakan perbedaan jenis kelamin, ras dan suku.

Untuk memahami konteks ayat dan hadis jika ditinjau dari perspektif fikih, maka perlu melihat asbāb al-nuzul dan asbāb al-wurud-nya. Ayat dan hadis tidak hanya dibaca secara tekstual dan tidak pula dianggap bahwa sudah menjadi pemahaman final, karena bisa jadi sebuah ayah dan hadis muncul tidak terlepas dari konteks sosial historis. Bisa jadi secara kontekstual pada saat itu kondisi kaum perempuan tidak sama kondisinya di era kekinian. Dengan kata lain, subtansi nash tadi, bukan berupa kalimat larangan (nahiy), tapi hanya khabariyah (berita). Hukum haram (larangan) pun tidak memiliki signifikansi yang akurat. Olehnya itu kepemimpinan perempuan perspektif fikih Islam bukanlah sebuah mani' (larangan), namun makna pemimpin yang dilarang menurut pemahaman fikih sebenarnya adalah perempuan yang berkuasa secara absolut seperti Raja atau Kaisar zaman dahulu.

Adapun kaitannya dengan konsep negara Indonesia pada masa kini adalah menganut sistem demokrasi, bahwa siapa pun boleh menjadi pemimpin selama memiliki kapabilitas. Selain itu berdasarkan prinsip demokrasi, kekuasaan negara dibagi menjadi tiga, yakni kekuasaan ekskutif (pemerintahan), kekuasaan legislatif (pembuat undang-undang), dan kekuasaan yudikatif (kehakiman). Jadi

\footnotetext{
${ }^{63}$ Kementerian Agama RI., Ummul Mukminin: Al-Qur'an dan Terjemahan, 847.
} 
jika seorang perempuan menjadi presiden di negara ini yang kekuasaannya hanya terbatas di bidang eksekutif, tidaklah dalam pengertian pemimpin yang dilarang, apalagi jika hanya menjadi menteri, atau pemimpin instansi tertentu saja, semuanya tentu dibolehkan.

Pemahaman fikih seperti di atas sangat cocok dalam konteks negara Republik Indonesia, dan pada gilirannya memberi peluang bagi kaum perempuan dan laki-laki untuk sama-sama berpeluang meraih kedudukan dan jabatan tinggi di tengah-tengah masyarakat, baik itu hakim, anggota parlemen, atau jabatan tertinggi sekalipun yakni sebagai kepala negara.

Paradigma fikih perempuan kontemporer meniscayakan perempuan untuk menjadi pemimpin, baik dalam ruang domestik maupun ruang publik. Paradigma fikih perempuan ini harus dibangun di atas landasan teologis yang menegaskan bahwa manusia sama di hadapan Tuhan, tanpa mengenal ras, suku, warna kulit, jenis kelamin dan sebagainya. Oleh karena itu paradigma fikih yang masih membatasi perempuan untuk berperan aktif di wilayah publik dipandang sebagai pandanga yang sempit dan substansial.

Perspektif fikih perempuan dalam konteks kekinian dan keindonesiaan meniscayakan suatu pemikiran yang berwatak dinamis dengan mempertimbangkan isu-isu universalisme, seperti keadilan, hak-hak asasi manusia, kesetaraan dan lain sebagainya yang tidak terbatas oleh ruang dan waktu. Watak yang demikian inilah yang menjadi ruh atau prinsip dalam konstruksi perempuan pada masa kekinian dan keindonesiaan.

\section{Kesimpulan}

Perempuan dalam pemahaman fikih harus didudukkan pada posisi yang sebenarnya, serta memberi peranan bukan saja dalam kehidupan rumah tangga, tetapi juga dalam kehidupan bermasyarakat. Konsep fikih perempuan dalam rumah tangga mengutamakan adanya mu'āsyarah bi al-ma'rūf. Sedangkan dalam masyarakat mengutamakan kesetaraan dalam memperoleh kedudukan (jabatan) sebagaimana kaum laki-laki. 
Fikih perempuan dalam konteks kekinian dan keindonesiaan menghendaki paradigma fikih yang mencerminkan kepada yang substansial untuk menjawab berbagai persoalan ketidakadilan terhadap perempuan yang berdasarkan keuniversalan yang harus diakui dan dihormati oleh manusia lain tanpa ada perbedaan yang memarginalkan manusia lain, utamanya kaum perempuan.

\section{Daftar Pustaka}

Aṣraf, Abū Muḥammad. Fatāwā al-Mar'ah al-Muslimah, Vol. 1. Riyad: Aḍwā' al-Salaf, 1996.

Darwis, Rizal. "Hak Nafkah Batin Isteri dan Kesetaraan Jender dalam Perkawinan: Analisis terhadap Konsep Hukum Islam dan Hukum Nasional Indonesia," dalam Abdul Wahid, et.al., Islam Indonesia Pasca Reformasi: Dinamika Keagamaan Pada Ranah Sosial, Politik, Budaya, Hukum dan Pendidikan. Cet. 1; Surabaya: Imtiyaz, 2015.

"Hak Nafkah Batin Istri dalam Perkawinan: Telaah Fikih dan Hukum Nasional Perspektif Jender," Disertasi. Makassar: UIN Alauddin Makassar, 2016.

. "Pemikiran Ibnu Qayyim al-Jauziyah terhadap Paradigma Perubahan Hukum," Adzkiya: Jurnal Hukum dan Ekonomi Islam, Vol. 05, No. 1, Maret 2017.

Fakih, Mansour. Analisis Gender \& Transformasi Sosial. Cet. VI; Yogyakarta: Pustaka Pelajar, 2008.

Haq, Hamka. Syariat Islam; Wacana dan Penerapannnya. Cet. II; Makassar: Yayasan Ahkam, 2003.

Harahap, Yahya. "Informasi Materi Hukum Islam: Mempositifkan Abstraksi Hukum Islam," dalam Cik Hasan Basri, ed., Kompilasi Hukum Islam dan Peradilan Agama. Jakarta: Logos Wacana Ilmu, 1999.

Ibn Manzur. Lisān al- 'Arabī, Juz 12. Bairūt: Dār al-Fikr, 1994.

Ibn Rusyd. Bidayah al-Mujtahid, Jil. 2, terj. Imam Ghazali Said dan Ahmad Zaidun, Bidayatul Mujtahid. Jakarta: Pustaka Amani, 2007.

Jabir, Muhammad al-Dausuqi dan Aminah. Muqaddimah fï Dirāsat al-Fiqh alIslämì. Qatar: Dauhah, 1411 H/1990 M.

Jamaa, La dan Hadidjah. Hukum Islam dan Undang-Undang Anti Kekerasan dalam Rumah Tangga. Cet. 1; Surabaya: Bina Ilmu, 2008.

Al-Jauziyah, Ibnu Qayyim. I'lam al-Muwaqqi'in 'an Rab al-'Alamīn, Juz III. Bairut: Dar al-Fiqr, t.th.

Kaff, Indrus H. Kamus Praktik Al-Qur'an. Bandung: Fokus Media, 2007. 
Muhammad, Husein. Islam Agama Ramah Perempuan. Cirebon: Fahmina, 2004. . Fiqh Perempuan. Yogyakarta: LkiS, 2001.

Mulia, Musdah. Ensiklopedia Muslimah Reformis: Pokok-Pokok Pemikiran untuk Reinterpretasi dan Aksi. Cet. 1; Tangerang Selatan: Baca, 2020. . Muslimah Reformis: Perempuan Pembaru Keagamaan. Cet. I; Bandung; Mizan, 1425 H./2005 M.

Nada,Qathrun. Sorotan terhadap Ide Rekonstruksi Fikih Perempuan: Sebuah Refleksi Semangat Pembaharuan, www.pesantrenonline.com

Rofiq, Ahmad. Hukum Islam di Indonesia. Cet. III; Jakarta: PT. Raja Grafindo Persada, 1998.

Sabiq, Sayyid. Fiqh Sunnah, Jil. 2. Madinah: Al-Fatkh li I'lām al-Arabì, 1990.

Sadari. "KDRT dalam Perspektif Fiqh," dalam Alimah (ed.), Ragam Kajian Kekerasan dalam Rumah Tangga. Cet. I; Cirebon: Institut Studi Islam Fahmina (ISIF) Cirebon, 2012.

Shaḥūur, Muḥammad. Al-Kitāb wa al-Qur'ān. Damaskus: Al-Ahālī, 1992.

. Naḥwa Ușūl Jadìdah li al-Fiqh al-Islämī: Fiqh al-Mar’ah. Damaskus: Al-Ahālì, 2000.

Shihab, M. Quraish. Wawasan Alquran: Tafsir Maudhu'i atas Pelbagai Persoalan Umat. Cet. III; Bandung: Mizan, 2003.

. Membumikan Al-Qur'an: Fungsi dan Peran Wahyu dalam Kehidupan Masyarakat. Cet. 1; Bandung: PT Mizan Pustaka, 2013.

Subhan, Zaituna. Kodrat Perempuan: Takdir atau Mitos. Cet. I; Yogyakarta: Pustaka Pesantren, 2004.

. Al-Qur'an dan Perempuan Menuju Kesetaraan Gender dalam Penafsiran. Jakarta: Prenada Media Group, 2015.

Al-Syatibi, Abū Ishaq Ibrāhim bin Mūsa. Al-Muwāfaqat fī Ushūl al-Aḥkām, juz 2. Kairo: Muhammad 'Ali Sabih, t.th.

Wardatun, Atun. Negosiasi Ruang antara RuangPublik dan Ruang Privat. Mataram: Pusat Studi Wanita IAIN Mataram, 2007.

Wibowo, Dwi Edi. "Peran Ganda Perempuan dan Kesetaraan Gender," Muwāzāh: Jurnal Kajian Gender, Vol. 3, No. 1, Juli 2011.

Zahrah, Abū. Ushūl al-Fiqh. Mesir: Dār al-Fikr al-'Arabì, t.th.

Zein, Satria Effendi M. "Hak Nafkah Batin Isteri dan Ganti Rugi Berupa Materi," Mimbar Hukum dan Aktualisasi Hukum Islam, No. 3 Tahun II, 1991.

Al-Zuhaili, Wahbah. Al-Fiqh wa Adillatuh, Juz 7. Beirut: Dār al-Fikr, t.th. 